University of Windsor

Scholarship at UWindsor

\title{
Creating an Anti-Corruption Norm in Africa: Critical Reflections on Legal Instrumentalization for Development
}

Paul D. Ocheje

University of Windsor, Faculty of Law

Follow this and additional works at: https://scholar.uwindsor.ca/lawpub

Part of the Other Law Commons, Public Law and Legal Theory Commons, and the Rule of Law Commons

\section{Recommended Citation}

Ocheje, Paul D.. (2017). Creating an Anti-Corruption Norm in Africa: Critical Reflections on Legal Instrumentalization for Development. Law and Development Review, 10.

https://scholar.uwindsor.ca/lawpub/34 
Paul D. Ocheje*

\title{
Creating an anti-corruption norm in Africa: Critical reflections on legal instrumentalization for development
}

DOI 10.1515/ldr-2017-0022

\begin{abstract}
This article reflects critically on the instrumental value of law in the anticorruption struggle in Africa. Three questions are central to this reflection: (a) Is the instrumental use of law to achieve a developmental purpose, such as anti-corruption, defensible in theory and practice? (b) Is law necessary to, and/or adequate for, the creation of an anti-corruption norm? (c) Why do the developing countries perform so poorly in the fight against corruption in comparison with their wealthier, industrialized counterparts? While the article defends the instrumentalization of law in this regard, it argues that the African normative context of corruption throws up peculiar challenges. The article suggests that these challenges must be confronted in order to liberate the full potential of law in the struggle against corruption.
\end{abstract}

Keywords: anti-corruption, legal instrumentalization, Africa, development, norms

\section{Introduction}

Legal measures abound today as the global weapon of choice in the fight against corruption. Most countries troubled by corruption ostensibly hope, through the enactment of laws, to create an anti-corruption norm, thereby to decrease the incidence of corruption to negligible levels. Clearly the upward trending of corruption in these countries has not as yet justified the overwhelming trust reposed in legal measures to do the job. For the global south, the lack of congruence between effort and results is quite telling, resulting in several questions at philosophical and practical levels. Some of these questions are: (a) Is the instrumental use of law to achieve a developmental purpose, such as anti-corruption, defensible in theory and practice? (b) Is law necessary to, and/ or adequate for, the creation of an anti-corruption norm? (c) Why do the developing countries perform so poorly in the fight against corruption in

*Corresponding author: Paul D. Ocheje, Faculty of Law, University of Windsor, Ontario, Canada, N9B 3P4; LLM (Benin), LLM., D.jur (Osgoode Hall Law School, York University), Ontario, Canada, E-mail: pocheje@uwindsor.ca 
comparison with their wealthier, industrialized counterparts? These questions are the subject of these reflections.

This article is developed in six stages. Part I describes the questions to be addressed, while parts II and III address the philosophical criticism of the instrumentalization of law from the perspective of the countries of the South, using those of Africa as example. Part IV discusses the attempt of African countries to instrumentalize law in their struggles against corruption and the peculiar challenges thrown up by the normative context of corruption. Part V relates the experience of some European countries where corruption has declined significantly and attempts to proffer reasons for the relative success achieved by these countries in constructing an anti-corruption norm. Part VI, the final part, attempts to draw lessons of history for African countries which are currently engaged in the anti-corruption struggle.

\section{Instrumental versus non-instrumental views of law}

There are two contending views about law and its purposes. One view sees law as a means to an end or as an instrument for achieving desired purposes either by government, citizens, or corporations or groups. The idea is very well established in the developing as well as in the Western world. The resort to law as an instrument of public policy or as a tool for the furthering of private and sectional interests is so habitual in common law jurisdictions that it is difficult to imagine a different role for law. This is particularly evident in the study of law and development. However, law and development scholars approach the subject from differing perspectives. Some take the basic function of law as conflict resolution. Conflict resolution is important, according to this view, in order to prevent conflicts from disrupting productive cooperation. Anarchy destroys society, but law integrates it. ${ }^{1}$ Therefore, the main function of law is to "create a milieu in which social and cultural diversities are harmonized, values essential to societal and governmental purposes are unified, and tensions resolved ... to maintain stability within a climate of desired, necessary and inevitable change."2 Of interest to these scholars generally are, for example, how the legal system functions, the interconnections between law and culture, the

1 See, e.g., H.C, Bredemeier, "Law as an Integrative Mechanism”, in W.M. Evan (ed.), Law and Sociology (New York: The Free Press of Glencoe, 1962), pp. 72, 74. See also T. Parsons, "The Law and Social Control”, in W.M. Evan (ed.), Ibid.

2 P. Proehl, “Book Review”, 42 Indiana L.J., no. 277 (1967). 
communication of law, legal transplantation, etc. ${ }^{3}$ In this way of studying law and development, there is no distinction between law and social change generally and law and social change under conditions of generalized poverty (ameliorating which is the real purpose or target of required social change in the developing world).

Other scholars take law as an instrument of social change. In their view, law's main function is problem-solving. The meaningful way to study law and development is to begin from the difficulties faced by the masses of the developing world. These difficulties include hunger, oppression, ignorance, disease, lack of potable water and sanitation, gender discrimination, etc. How to solve these difficulties, according to this view, ought to be the domain of study for law and development scholars. ${ }^{4}$

The American socio-legal scholar, Brian Tamanaha, recently launched a blistering critique of the instrumental view of law. For him, the law is an embodiment of the "common good". ${ }^{5}$ The law stems from society's natural or moral order; being a "pre-given order that encompassed everyone ... a law for all that was the product of no-one". For him, there is "a necessary content and integrity" to law. He does not find anything necessarily objectionable about the use of law as a means to an end if that end is tied to the idea of the common good. But, he argues, using law as a mere tool, without an appreciation of some underlying inherent values essential to it, is dangerous for society. He contends that law, bereft of this essential quality, becomes a ready tool for the pursuit of special interests with nary a consideration of the effects of such pursuit on the common good. When this happens, the rule of law is threatened by cynicism about law as a system of ideas, and about the various agencies that give law its practical relevance. The legislature may then be dismissed as a mere tool of special interests which churns out law, not necessarily for the common good, but in furtherance of partisan agenda of domination. Decisions of judges may become subject to suspicion regarding judicial or legal objectivity. Lawyers may also lose respect in the eyes of the public if they conceive of their role in the administration of justice as merely to serve the interests of their clients without concern for the wider societal interests or the common good. ${ }^{6}$

3 See, e. g., L. Friedman, Legal Culture and Social Development, 4 Law and Society Review, no. 29 (1969); D.M. Trubek, Toward a Social Theory of Law: An Essay on Law and Development, 82 Yale L.J., no. 1 (1972).

4 See, e. g., R.B. Seidman, The State, Law and Development (London: Croom Helm, 1978), 15-16. 5 B.Z. Tamanaha, Law as a Means to an End: Threat to the Rule of Law (Cambridge: Cambridge University Press, 2006).

6 See also reviews of Tamanaha's book by Roger Cotterrell, Is Law Just a Means to an End?, The Socio-Legal Review (National Law School of India University): http://www.sociolegalreview.com/ is-law-just-a-means-to-an-end/ accessed Dec. 4, 2016; and M. Del Mar, 66 The Camb. L.J., no. 2 (July 2007), 468-471. 
Tamanaha's critique of legal instrumentalism raises salient questions, at any rate, when it is held up against the circumstances of the developing world. Does this idea of law as commonly shared values with necessary content and integrity resonate with developing, formerly colonized territories of the world, or is this just a Eurocentric understanding of the law? How does law imposed by, or modeled on the law of, a foreign country encompass the shared values of the indigenous community? Answers to these questions expose the limited relevance of the critique of legal instrumentalism to most of the world outside of America and Europe (and, perhaps, the settler colonies of Australia and New Zealand). Part of the colonial project in Africa was to break down or relegate to an inferior position the indigenous laws and traditions of the colonized territories. ${ }^{7}$ The laws and traditions were severely pruned of their essences and their continued operation made subject to "natural justice, equity and good conscience". Just what amounted to "natural justice" "equity" and "good conscience" was never defined, but, taken together, these were a catch-all formula for the exercise or superimposition of the whims of the colonial power on indigenous notions and understandings of the common good. ${ }^{8}$ The common law as a system of ideas never emanated from the colonized peoples or territories. Constitutions and structures of governance were never truly autochthonous even though abundant lip service was paid to "consultation".9

Successors of the colonial state have not done better. Most developing countries, except perhaps those of the Asian sub-continent, are riven by social, economic, and political dualisms. The law was a predominant part of these dualisms; it sanctioned and encouraged cultural and economic solitudes within the colonized territories, making any talk about a common good nonsensical. An economic dualism has entrenched "enclave" economies in the independent countries, in which modern economies of stock markets, banks, industries, etc. co-exist with informal traditional economies which subsist on trust and reciprocity. The dual economy is responsible for the inequitably skewed income distribution in which only $5 \%$ of merchants and exporters control $95 \%$ of national income. A phenomenon that is becoming more frequent in modern Africa is the predatory relationship between the modern and the traditional economies. State power is often used by governments to extort taxes or otherwise deprive rural farmers and peasants of

7 See, e. g., M. Mamdani, Citizen and Subject: Contemporary Africa and the Legacy of Late Colonialism (Princeton: Princeton University Press, 1996).

8 See, e.g. R.N. Nwabueze, The Dynamics and Genius of Nigeria's Indigenous Legal Order, 1 Indigenous L.J., (Spring, 2002), 153-200.

9 See, e.g. S.N. Merry, Colonizing Hawai'i: The Cultural Power of Law (Princeton: Princeton University Press, 2000). 
the proceeds of hard labor on the farms. Political dualism is evident in the elitist nature of African politics, in which the bulk of the masses, poorly educated, indigent and vulnerable, are excluded and marginalized.

Given this history of oppression and dualism, any criticism of legal instrumentalism would require more for resonance in Africa than that the instrumental use of law is liable to deprive law of a transcendental content and integrity. Insofar as a common value can be identified among the populace of African countries, it is the elimination of poverty, ignorance, and vulnerability.

\section{The imperative of legal instrumentalization for development in Africa}

Development is goal-directed behavior. It connotes social change from one form of behavior to another. Institutional schools of social science agree that each society is defined by its institutions, that is, the repetitive patterns of behavior among its members. ${ }^{10}$ A university, for example, is called an educational institution, not because of the buildings that occupy its premises, but because those who populate the premises behave in repetitive patterns: professors teach students and carry out research; students attend classes and are evaluated at each stage of learning, and so on. African countries are poor because African peoples and governments repetitively behave in patterns that reproduce poverty. ${ }^{11}$ For example, farmers use crude implements to till reluctant soils which, in turn, produce food sufficient for only subsistent livelihood. Their enclave economies produce wealth for multinationals and condemn the vast majority of the citizens to wage labor in the mines and commercial farms. To change society, the institutions of society must change.

Norms, supported by sanctions, define repetitive patterns of behavior. In modern society, law or the legal order is part of the normative system. It contains "rules ... and the processes by which they are promulgated,

10 See, e. g. W.R. Scott, Institutions and Organizations: Ideas, Interests and Identities, 4th ed. (Los Angeles: Sage Publications, 2014); J. Burns, The Dynamics of Accounting Change Interplay Between New Practices, Routines, Institutions, Power and Politics, 13 Accounting, Auditing and Accountability Journal, no. 5 (1988), 566-596; D. North, Institutions, Institutional Change, and Economic Performance (New York: Cambridge University Press, 1990); and E. Ostrom, Governing the Commons: The Evolution of Institutions for Collective Action (New York: Cambridge University Press, 1990).

11 See A. Seidman \& R.B. Seidman, State and Law in the Development Process: Problem-Solving and Institutional Change in the Third World (New York: St. Martin's Press, 1994). 
communicated or sanctioned"12 by the officials of state. That is why some scholars refer to the legal order as "governmental social control" 13

\subsection{The relationship of law to development}

The relationship between law and development arises from the acknowledged duty of the state to induce and channel social change in desired ways. The days are no more when the church, the village or the clan determined the course of social change. In those days, society consisted of small and close-knit communities. In Africa, villages and small settlements were populated by people of mostly homogenous cultures and values, and cities were very few and far between. In these precolonial communities, social change did occur, but it was quite incremental and without specific direction. By contrast, the post-colonial fast and complex society represents great transformation from the relatively simple kin-oriented and agricultural subsistence lifestyles. The states which have emerged in Africa at the end of colonialism are confronted with a myriad of challenges in regard to the transformation of institutions to make them suitable to the generation of wealth, amelioration of poverty, democratization of politics, and all of the changes necessary to modernization. In other words, the modern state must induce social change in a goaldirected way, rather than allow an unhurried and unchanneled change by social processes. The law or legal order is the most effective instrument for this task. As Seidman ${ }^{14}$ writes, to induce change

\footnotetext{
Only the state ordinarily has sufficient capacity, resources or legitimacy to undertake such a formidable task. Typically, the state tries to induce development by changing the rules defining repetitive patterns of behaviour, by directing its officials to act in new ways - that is, by changing the legal order. Demands for development therefore appear as demands for new law: new rules of land tenure, marketing boards, planning machinery, electoral politics, educational systems, monetary systems, taxation.
}

Law intersects with development in yet another way: it co-ordinates the high degree of specialization and exchange that is the hallmark of modern society. This involves the transformation of networks of individual relationships into obligations to the community. In the modern society, as one writer puts it, “[M]odernization requires a whole range of new, specialized roles. This can only succeed if the persons who occupy them mesh their activities with each other. This requires a high degree of co-

12 R.B. Seidman, supra note 4, at p. 16.

13 See D.J. Black, The Boundaries of Legal Sociology, 81 Yale L.J., (1972), 1086, at p. 1096.

14 R.B. Seidman, supra note 4, at p. 17. 
ordination". ${ }^{15}$ For example, those who specialize in a particular trade, say the production of textile, need to know that others would specialize in the production of food so that they can acquire food and not starve; they need to know that others would create and maintain a market where they could sell their goods; and that they can tailor their production to actual demand by buyers who must be held to the contract of sale, and so on. Specialization and exchange thrive on order and a high level of certainty. As one commentator notes, "law is the most available instrument to define, create, enforce and co-ordinate these obligations."16

In sum, unlike other social control mechanisms, law is tailor-made to induce change in patterns of social behavior. Other social control mechanisms try mainly to ameliorate conflict. Law is especially significant in conditions of development because the important goal is not necessarily the restraint of deviance from the status quo but the inducement of new forms of behavior. In this regard, and in spite of its manifest limitations, ${ }^{17}$ law has been characterized as "the most available instrument to induce social change". ${ }^{18}$

\subsection{The contingency of law}

To state the availability of law as an instrument for social change says nothing about its effectiveness. Is law an effective instrument in this regard? The answer is yes and no. Law, when used in a receptive environment can be very effective in changing patterns of social behavior, but in other less favorable environments, the law can fail to induce desirable behavior. In other words, the effectiveness of law is essentially contingent. An elementary understanding of the contingency of law in directing social behavior must begin with the acknowledgement that law, for success, often harnesses what Eric Posner ${ }^{19}$ describes as "the independent regulatory power of social norms". He continues:

These efforts (to harness the regulatory power of social norms) sometimes succeed and sometimes fail; what is important to understand is that social norms are unlikely to change as a result of simple, discrete, low-cost interventions by the government, although proposals along these lines are sometimes found in the literature, and that attempts to intervene are risky because social norms are complex, poorly understood, and sensitive to factors that are difficult to control.

15 F.W. Riggs, "Modernization and Political Problems: Some Developmental Prerequisites", in W.A. Beling and G.O. Totten (eds.), Developing Nations: Quest for a Model (New York: Van Nostrand Reinhold, 1970), p. 11.

16 R.B. Seidman, supra note 4, at p. 18.

17 See, e. g., A. Allott, The Limits of Law (London: Butterworths, 1980).

18 R.B. Seidman, supra note 16.

19 E. Posner, Law and Social Norms (Cambridge, Mass.: Harvard University Press, 2002), at p. 8. 
There is, thus, a close relationship between law and norms, a relationship that underscores the contingency of law as an instrument of social engineering. Without a conducive social norm, it is unlikely that law may change social behavior. On the other hand, the law may be useful in undermining bad social norms.

\subsection{African countries and the persistence of corruption}

In Africa, corruption has been identified as the greatest difficulty in the effort of governments to drive development. ${ }^{20}$ Billions of dollars are lost on a routine basis to embezzlement, misappropriation of funds, and theft of public funds. ${ }^{21}$ The diversion of public resources to private pockets is so widespread, and poverty has festered among the populations of African countries for so long, that the continent can be correctly characterized as underdevelopment's last stand. However, the combined international and domestic efforts over decades to create an anti-corruption norm in these countries, backed by laws specifying tough penalties for violation, have not succeeded. ${ }^{22}$ The failure to instrumentalize law in this respect invites an examination of the social norms that have entrenched corruption among the populace.

In Nigeria, for example, the current regime, led by Muhammadu Buhari, has made anti-corruption one of its main governance objectives. Nigeria has been troubled by widespread corruption, which has resulted in many development failures over the decades. Corruption among government officials has also led to mass impoverishment of the citizens, and threatened the corporate existence of the country. There is currently a massive crackdown on corruption by the government, much of which is directed at recovering billions of dollars that have been stolen or misappropriated by public officials. There are many cases pending in court in this regard. However, in addition to utilizing the legal machinery, parallel actions are being taken to reform the public accounting system to block the loopholes in the administrative apparatus which have made theft of public funds to be relatively without risk, and to implement checks and balances that would make such difficult and risky. One recent initiative is the Treasury Single Account (TSA), which

20 See, e.g., John M. Mbaku, Corruption in Africa: Causes, Consequences, and Cleanups (Lanham: Lexington Books, 2007).

21 See, e.g., D.J. Smith, A Culture of Corruption: Everyday Deception and Popular Discontent in Nigeria (Princeton: Princeton University Press, 2008); R. Joseph, Democracy and Prebendal Politics in Nigeria: The Rise and Fall of the Second Republic (Cambridge: Cambridge University Press, 1988).

22 Several reports, e.g., since this Millennium by the international anti-corruption watch-dog, Transparency International, indicate a rising trend, rather than a decline, of corruption. 
centralizes government funds in a single account, as opposed to the innumerable separate accounts set up by agencies and other bodies, most of which had escaped the supervision of the government. In tandem with this reform of public accounting processes are other reforms, including the computerization of revenue collection and payment systems. ${ }^{23}$ A barrage of anti-corruption laws, some of which were in existence on the books before the advent of the current government, have been deployed, though with mixed results. It is clear to observers of the Nigerian situation that the social norms which have created a wide tolerance for corruption among the citizens are still very strong and are breeding considerable resistance against government's anti-corruption norm entrepreneurship. ${ }^{24}$

The story of Nigeria is replicated in many African countries. There is not much success with the anti-corruption drive in these countries chiefly because social values and norms have not yielded in any significant way to the new directions offered by the leaders. In most cases, the leaders do not practice what they preach; in others, there are structural difficulties erected by the colonial and historical legacies of these countries.

\section{Creating an anti-corruption norm: The African experience}

Given the relevance of legal instrumentalization in Africa for purposes of development, it is important to explore the use of law in the transformation of the normative landscape that accommodates corruption. We begin by describing the landscape.

23 In addition to the offences contained in the Penal Code and the Criminal Code relating to any form of tampering with public funds, there are numerous other offences created under the Economic and Financial Crimes Commission (Establishment) Act; the Independent Corrupt Practices and Other Offences Commission (Establishment) Act; the Fiscal Responsibility Act; the Public Procurement Act, the Anti-Money Laundering Act, and so on.

24 There have been many instances of some individuals and ethnic groups mobilizing in support of persons accused of corruption since the present government began its crack-down on corruption. For the latest, see, e. g., the Premium Times newspaper report at $<$ http://www.premiumtimesng. com > of October 26, 2016, titled “\$15 million: Ijaw women protest in support of Patience Jonathan". The resistance comes from lawyers and judges who have shown by their conduct that they do not support the anti-corruption project, and even from employees of the primary anti-corruption agency, the Economic and Financial Crimes Commission: see, e. g., "There is corruption everywhere, including in EFCC - Magu”, Premium Times (Nigeria), December 2, 2016; Vanguard News (Nigeria) "Judicial Corruption: FG slams 15-count charge against Justice Ademola, wife": < http:// www.vanguardngr.com >, November 15, 2016. 


\subsection{The existing normative context}

In Africa, the normative context of corruption can be described as resistant, even antagonistic, to the drive for anti-corruption. It is characterized by the following:

(a) A Dual Conception of the "Public" Sphere: In Africa, the public/private distinction, which has helped in these past few centuries to order society in the West and to clarify the notion of corruption, is either non-existent or is not helpful owing to the dual conception of the "public". ${ }^{25}$ A sharp distinction between the public and the private is necessary in any fight against corruption because the fight is about preventing wielders of public power from privatizing public resources. An important step in the anti-corruption struggle historically has been the unification of both private and public moral standards, such that what is wrong in one's private judgment would also be wrong in terms of public morality. However, a rather strange lack of private and public moral coincidence is plainly observable in Africa. The modern "public" of the civil service, the army, the police, banks, industries, businesses, etc., was a creation of the colonial administrations. It exists side by side with the traditional public of villages, tribes, clans of the vast rural expanses that exist in every country. While the traditional public is regarded as moral by the populace, the modern public is considered to exist in an amoral sphere. Theft, extortion and misappropriation of property may be considered morally wrong in the traditional society, but the same wrongs are viewed with indifference when they occur, or even encouraged, in the modern sector by the same society. In most countries, the colonial relationship with the rural sector was characterized by immoral behavior - extortion, theft, forcible seizure of property, human rights violation, etc. These traumatized and alienated the citizens and drove a wedge between them and the face of modernity - the government. Unfortunately, succeeding African leaders have left the gulf created by the departing colonial authorities unrepaired. Several nation-building attempts have foundered on the alter of greed, abuse of power, lack of vision and continuing violation of human rights.

(b) Economic Stagnation: Most African countries suffer from economic stagnation, which has translated into poverty of a massive scale. Civil servants are poorly paid and are often in search of illegitimate means to augment their salaries and wages. Lack of economic growth has constricted opportunities for investment in independent and productive economic activities rather

25 See the seminal analysis of P. Ekeh, Colonialism and the Two Publics in Africa: A Theoretical Statement, 17 Comparative Studies in Society and History, no. 1 (1975), 91-112. 
than rent-seeking. The failure to industrialize means that African economies are condemned to be producers of raw materials with ever fluctuating and vulnerable prices, as opposed to the stable and ever rising prices of manufactured products in the international market. In addition, in spite of all the optimism generated by or associated with globalization, the African economy is typically "enclave", some say "dual", in nature. It consists of a tiny export enclave which feeds on a larger rural periphery, paying pittance for export crops. It creates poverty for a majority of the citizens while concentrating wealth at the center for the merchants, the banks, the corporations, and corrupt civil servants, the police, and the army.

(c) Democratic Deficits Leading to a "Rationality of Fear": Attempting to build a nation from the top is fraught with uncertainties and, sometimes, human rights violations. Such a task, in Africa, involves galvanizing disparate ethnic groups who have yet to detach themselves from their traditional sources of security which are intertwined with their totemic allegiances. For many, the modern state, imposed on these groups by an accident of history, has yet to prove its merit in terms of providing a rallying point for the actualization of a common destiny. Abuse of power and impunity remain a routine feature of governance. In these circumstances, it is rational to fear for the future. ${ }^{26}$ This fear translates into a willingness to corner or squirrel away resources by individuals who have access to public resources in an attempt to secure the future for themselves and their families.

These characteristics of the African normative context for the anti-corruption effort are often ignored by leaders in the enactment of laws against corruption. With deep-seated elements of the social norm such as these, it appears elementary that, to ensure reasonable prospects for the effectiveness of the laws, the norms must change drastically.

\subsection{Challenging the normative context}

Norms have been defined as standards of appropriate behavior for actors within a given community. As Eric Posner notes, social norms are sometimes desirable and sometimes odious, and the law is critical to enhancing good social norms

26 For the concept of "Rationality of Fear", see B.R. Weingast, "Constructing Self-Enforcing Democracy in Spain”, in I.L. Morris et al. (eds.), Politics from Anarchy to Democracy (Stanford: Stanford University Press, 2004), pp. 161-195. 
and undermining bad ones. ${ }^{27}$ To challenge or supplant existing norms, constructivist theorists tell us that there are three stages in the dynamics that lead to the emergence of a norm. The first stage is norm entrepreneurship. "Norms do not appear out of thin air" state Finnemore and Sikkink, ${ }^{28}$ and they never occur in an empty space: they emerge within a normative framework and compete with standards of "appropriateness" defined by existing norms and perceptions. Norm entrepreneurs, that is, agents who have strong notions about appropriate behavior in their community, call attention to social patterns of behavior which they consider to be inappropriate. Norm entrepreneurs require a platform from which to promote their norms, such as a governmental or Non-Governmental Organization. If they succeed in winning enough converts to their position, then the new norm reaches the "tipping point". Then follows the second stage of norm cascade in which the norm begins to "cascade" into the community, and more members begin to subscribe to the norm without any pressure. Finally, the norm is internalized, the acceptance of it having become so routine that conformance with it is almost automatic.

It is part of the difficulties associated with fighting corruption in divided societies, such as in Africa, that ordinarily it is only the government which has the requisite resources and reach to potentially become an effective norm entrepreneur. Governments in Africa have spearheaded the drive for a new social norm of anti-corruption, using the law to help install it. But because of the various elements of the existing normative context, persuading the populace to subscribe to a new standard of appropriateness from the top has met with uneven results. In addition to these elements, the governments do not have the credibility, nor do they have the resources to actualize a durable change in the attitudes of their populations toward corruption. Sometimes, government crusades against corruption are perceived as naked political vendetta against opponents ${ }^{29}$; at other times,

27 E.Posner, supra note 19.

28 See, e.g., M. Finnemore and K. Sikkink, International Norm Dynamics and Political Change, 52 International Organization, no. 4 (1998), 887-917 . See also generally C. Bicchieri, The Grammar of Society: The Nature and Dynamics of Social Norms (Cambridge: Cambridge University Press, 2006).

29 See, e.g., J.M. Mbaku, Bureaucratic Corruption in Africa: The Futility of Cleanups, 16 The Cato Journal, no. 1 (Spring/Summer, 1996); D.J. Smith, A Culture of Corruption: Everyday Deception and Popular Discontent in Nigeria (Princeton: Princeton University Press, 2007), pp. 227-228. See, e.g. also, "The needless vendetta in Buhari's anti-corruption crusade”, Vanguard (Nigeria), 19 September 2015: <http://www.vanguardngr.com/2015/09/the-needless-vendetta-in-buharisanti-corruption-crusade/ >, accessed 4 December 2016; The Star (Kenya), "Uhuru to Name, shame Corrupt Public Servants”, 3 August 2015:<http://allafrica.com/stories/201508030119. html >, accessed 4 December 2016; in Malawi, The Nation reports: “ACB drops case against 
governments prove the opponents right by failing to account for wealth recovered from officials prosecuted and found guilty of corruption. In some African countries, the machinery of justice has been implicated in corruption, stripping the judicial system of the trust so fundamental to respect for its vital role in the fight against corruption. Legislators in many African countries, often at the receiving end of corruption allegations, are quite antagonistic to powers granted to corruption investigatory and prosecuting bodies. ${ }^{30}$

In consequence, the anti-corruption norm entrepreneurship in most African countries is stuck at the first stage of the dynamics of norm emergence. To move the dynamics along to the second and last stages would include a recognition, and removal, of the underlying obstructions to change.

\section{An example in history: The decline of corruption in Europe}

Corruption troubles all nations today to a more or less degree. ${ }^{31}$ There is no doubt that some countries suffer more egregious consequences of corruption than others. In the case of African countries, it has been recognized in development discourse that corruption is the greatest obstruction to development and, therefore, the greatest cause of poverty on the continent.

Historical evidence suggests that Europe was once troubled by the kind of corruption that currently troubles African countries. ${ }^{32}$ The central feature of corruption is the abuse of power which is often demonstrated by the privatization of public resources. Although there is a singular lack of systematic treatment of corruption as a historical phenomenon in Europe, there seems to be a consensus among historians that corruption, such as the sale of public office,

former Malawi VP”, 20 September 2014:<http://mwnation.com/acb-drops-case-against-formermalawi-vp/>, accessed 4 December 2016.

30 Such attempts to weaken the powers of anti-corruption agencies have been seen in Nigeria and Kenya lately: see, e.g., the Kenyan National Assembly Official Report (Hansard) of Thursday, 13 September 2007, at p. 3925, and The Guardian (Nigeria), "National Assembly takes over control of CCB/CCT from presidency”, 28 October 2016:<http://guardian.ng/news/nationalassembly-takes-over-control-of-ccb-cct-from-president/ >, accessed 4 December 2016.

31 See, e.g., L. Cockcroft, Global Corruption: Money, Power, and Ethics in the Modern World (Philadelphia: University of Pennsylvania Press, 2012).

32 See, e.g., M. Genaux, "Early Modern Corruption in English and French Fields of Vision”, in A. J. Heidenheimer and M. Johnston (eds.), Political Corruption: Concepts and Contexts, 4th ed. (New Brunswick, NJ: Transaction Publishers, 2002), pp. 107-121; and J. van Klaveren, “Corruption as a Historical Phenomenon”, in Heidenheimer and Johnston, Ibid., 83-94. 
was endemic in eighteenth century politics of England and continental Europe. ${ }^{33}$ According to one commentator, there was "widespread use of pensions, sinecures, and gratuitous emoluments granted to persons whom the British government, between the earlier eighteenth century and the Age of Reform, wished to bribe, reward or buy. It was an all-pervasive feature of British politics in this period - indeed, among the elements which most distinguished eighteenth century British politics from that of the nineteenth ..."34 The decline of corruption in England, Germany, or Denmark was a gradual process. Improvements in England coincided with the industrial revolution, and in Germany and other places, more improvements occurred in the turn of the nineteenth century. ${ }^{35}$

It has been shown that in Denmark, the fight against corruption was waged for over 350 years, with the level of corruption significantly reduced only by the middle of the nineteenth century. The fight was part of state-building efforts since about 1660, when the absolute monarchy was established. As another commentator notes ${ }^{36}$

The institutional framework set up at this point along with continuing reforms to improve the administration in the period of absolutism between 1660 and 1849 came to form an important basis for an administrative culture based on the rule of law which came to minimize corruption. The building of the absolute monarchial state power came to be ensured through the establishment of a strong and comprehensive state hierarchy with a king at the top who set out to guarantee the rule of law and attempted to be merciful to his subjects. The king was not only head of state but also the secular leader of the Lutheran state church, and Lutheran-based values and institutions were reinforced in the governance of the country. These elements in combination with the establishment of an increasingly Weberian bureaucracy after 1660 helped to curb corruption in the Danish

33 K.W. Swart, The Sale of Public Officies, in Heidenheimer and Johnston, supra note 28, pp. 95-106.

34 W. Rubinstein, The End of "Old Corruption" in Britain 1780-1860, Past and Present, no. 101 (1983), 55.

35 W. Doyle, Changing Notions of Public Corruption, C. 1770-C.1850, in E. Kreike and W.C. Jordan (eds.), Corrupt Histories (Rochester, NY: University of Rochester Press, 2004), pp. 83-95; W. Prest, Judicial Corruption in Early Modern England, Past and Present, no. 133, 67-95; P. Harling, The Waning of 'Old Corruption': The Politics of Economical Reform in Britain, 1779-1846 (Oxford: Oxford University Press, 1996); and T. Kerkhoff et al., Corruption and the Rise of Modern Politics in the Eighteenth and Nineteenth Centuries: A Comparison Between France, the Netherlands, Germany and England at https://www.academia.edu/2906809/Corruption_and_the_Rise_of_Modern_Politics_ in_Europe_in_the_Eighteenth_and_Nineteenth_Centuries_A_Comparison_between_France_the_ Netherlands_Germany_and_England; accessed on 3 December 2016.

36 M.F. Jensen, The Question of how Denmark got to be Denmark: Establishing rule of law and fighting corruption in the state of Denmark 1660-1900, QoG Working Paper Series, 18 November 2014; A. Mungiu-Pippidi, The Quest for Good Governance: How Societies Develop Control of Corruption (Cambridge: Cambridge University Press, 2015). 
administration of state, and this is likely to have played a key role in establishing Denmark's present high level of quality of government and global position as a best performer in terms of fighting corruption.

Part of the legal and administrative reforms in Denmark at the beginning of the nineteenth century was the raising of civil servants' salaries so that "civil servants in general had become part of the well-to-do middle class and pensions were guaranteed in the Danish constitution of 1849."37 All in all, these reforms and the political will of the kings and top lieutenants to consistently discourage corruption by stern condemnation were responsible for the change in the attitude of civil servants. Augmenting their income by corrupt means became risky compared to working honestly and being guaranteed a pension. ${ }^{38}$

France was another country that had to tackle corruption. There, a host of ills were frontally confronted through the Revolution of 1789. William Doyle states that "the Revolution had, in fact, achieved at one blow what ... took several generations in Britain ... [T] he men of 1789 were determined to abolish a complex of behaviour and practice - privilege, monopolies, nepotism, and patrimoniality - that was not unlike Old Corruption across the channel. It was not held together by the requirements of parliamentary management, but it was just as all-pervasive in the way public affairs were run in France." 39 Still, the process of abolishing venality in France was not easy, even if it was relatively faster than it was in Britain. There were about seventy thousand venal office holders, all of whom had to be compensated for their dispossession, a process so expensive that it was almost aborted at a point. The compensation offered was substantially less that the market value of the offices, and this led to dissatisfaction among the officeholders. But by 1794, this process was completed, and "an institution condemned from the start as corrupt, but which had grown and flourished, seemingly unstoppably, over five centuries" 40 had been abolished. The functions formally performed by the officeholders were now opened to be competed for on merit, and, with time, a professional civil service was established.

Through various processes of reform over centuries, corruption generally declined in Europe. The causes of the decline were socio-political and economic.

37 M.F. Jensen, Ibid.

38 Ibid.

39 W. Doyle, supra note 31, at p. 91. See also his Venality: The Sale of Offices in 18th Century France (Oxford: Oxford University Press, 1996), and K. Swart, The Sale of Public Office, in Heidenheimer and Johnston, supra note 28.

40 Ibid., at p. 92. See also W. Doyle, The Origins of the French Revolution, 3rd ed. (Oxford: Oxford University Press, 1999), pp. 5-41. 
In political terms, changes in political and philosophical thinking in the eighteenth and early nineteenth centuries created a supportive environment for the abandonment of all practices associated with absolutism, and a movement toward democracy. With the emergence of the modern idea of the state came the conception of public office as public trust, rather than private property or benefice, and the state as a moral entity and the exercising of public office as a duty. As Hill notes, corresponding to these changes and the gravitation towards liberal democratic ideas were such values as "neutrality, impartiality, merit, and egalitarianism and pitted them against the absolutism, nepotism, particularism, and patronage perceived to be attendant on feudal and aristocratic forms of governance." 41

Another explanation for the decline in corruption in Europe was economic prosperity. Sustained economic growth, it has been explained, ${ }^{42}$ expanded opportunities for entrepreneurship and productive investment, thereby undermining the urge for rent-seeking investment. Besides, economic growth could also have reduced the urge for civil servants to corrupt their offices by making the resources available to pay them generous compensation.

Given this history, it must be acknowledged that the African experience with corruption is not uniform. Certain countries, such as Botswana, Mauritius, and to some extent, Rwanda, appear to be bucking the trend of economic stagnation. ${ }^{43}$ These countries are positioning themselves to effectively combat corruption. The differences between these countries and most other African countries lie in their differential historical circumstances. While Rwanda appears to be reaping the rewards of effective integration with the global information technology revolution, Botswana and Mauritius have a long record of democratic institutionalization. ${ }^{44}$ Together, the contemporary experiences of these countries tend to lend credence to the historical trajectory which the reduction of corruption followed in the wealthier industrialized countries.

41 L. Hill, Adam Smith and the Theme of Corruption, 68 The Review of Politics, (2006), 636-662. 42 See, e.g., P. Bardan, Corruption and Development: A Review of Issues, 35 Journal of Economic Literature, no. 3 (1997), 1320-1346.

43 See, e.g., A.S. Samatar, An African Miracle: State and Class Leadership and Colonial Legacy in Botswana Development (Portsmouth, NH: Heinemann, 1999); J.C. Leith, Why Botswana Prospered (Montreal \& Kingston: McGill Queen's University Press, 2003); M. Tafirenyika, Information Technology Super-Charging Rwanda's Economy, Africa Renewal (April, 2011): < http://www.un.org/africarenewal/ >; accessed 4 April 2017.

44 See, e.g., R. Sandbrook et al., Social Democracy in the Global Periphery: Origins, Challenges, Prospects (Cambridge, UK: Cambridge University Press, 2007). 


\section{In conclusion: The lessons of history}

In concluding these reflections, it is well to note that even in the European countries, which we have used as examples of the decline of corruption, corruption has not ended. Globally there is yet to emerge a fool-proof formula for ending this social behavior. This has led one commentator to observe that there is need for caution "about the lessons one can draw from (the historical examples of the decline of corruption). While generally it can be possible - and the global anti-corruption movement does indeed benefit from lessons learned in various places and time periods - one needs to keep in mind the cultural, political and economic differences of different places and different times. ${ }^{\circ 5}$ In contrast with the European experience, Hong Kong, an Asian country, scores highly on Transparency International's Corruption Perception Index (at No. 18 out of 175 countries in 2016); so does Botswana in Africa, which was ranked No. 28. It is not a coincidence that these countries are also economically prosperous. Nevertheless, certain useful lessons can be extracted by African countries from these reflections:

First, the law appears to be the greatest instrument for inducing social change, and, given their historical circumstances, criticism of legal instrumentalism fails to detract from the inherent usefulness of law as a tool for development. Secondly, a sophisticated understanding of the symbiotic relationship between norms and the law, as described above, means that more attention must be paid to the emergence of norms as enablers of law in the fight against corruption. Thirdly, corruption is a resilient phenomenon and the aim must be to drastically reduce it in the short term, the better to prevent the hemorrhage of resources badly needed for nation-building; if older nations are still being challenged by it, it follows that eliminating it is a gradual, long-drawn process. A useful starting point might be to begin to deepen democracy, stimulate economic growth, and reduce the level of poverty on the continent.

Acknowledgment: This is a revised version of a paper delivered at the 2016 Law and Development Conference held at Buenos Aires, Argentina (October 21-22). I am grateful to the Law and Development Institute and the facilitators of this conference, Professor Y.S. Lee of the institute and Professor Stephanie de Moerloose of University Austral, Buenos Aires, for the opportunity. Many thanks for all the comments by participants and my colleagues at the University of Windsor Law School, which helped to sharpen my arguments and perspectives

45 F. Ramseger, Historical Perspectives on Corruption in Europe, Utstein Anti-Corruption Centre, 26 February, 2007:<http://www.u4.no/publications/historical-perspectives-on-corruption-ineurope/ > , accessed 4 December 2016. 
at various points in this article. I would also like to acknowledge the generous financial assistance of the University of Windsor through the Academic Development Travel Grant program, as well as the supplementary assistance provided by Chris Waters, Dean of the University of Windsor Law School, which made my trip to Argentina possible and comfortable. To the best of my knowledge, all of the information provided in this article is accurate at the date of submission, but any errors are my responsibility and mine alone.

\section{References}

Allott, A., The Limits of Law (London: Butterworths, 1980).

Bardan, P., Corruption and Development: A Review of Issues, 35 Journal of Economic Literature, no. 3 (1997), 1320-1346.

Bicchieri, C., The Grammar of Society: The Nature and Dynamics of Social Norms (Cambridge: Cambridge University Press, 2006).

Black, D.J., The Boundaries of Legal Sociology, 81 Yale L.J. (1972), 1086 at p. 1096.

Bredemeier, H.C., "Law as an Integrative Mechanism", in W.M. Allen (ed.), Law and Sociology (New York: The Free Press of Glencoe, 1962).

Burns, J., The Dynamics of Accounting Change Interplay between New Practices, Routines, Institutions, Power and Politics, 13 Accounting, Auditing and Accountability Journal, no. 5 (1988), 566-596.

Cockroft, L., Global Corruption: Money, Power, and Ethics in the Modern World (Philadelphia: University of Pennsylvania Press, 2012).

Cotterrell, R., Is Law Just A means to an End?, The Socio-Legal Review (National Law School of India University): <http://www.sociolegalreview.com/is-law-just-a-means-to-an-end/

Del Mar, M., Book Review, 66 The Camb.L.J., no. 2 ((July, 2007), 468-471.

Doyle, W., Venality: The Sale of Offices in 18th Century France (Oxford: Oxford University Press, 1996).

Doyle, W., "Changing Notions of Public Corruption, C. 1770-1850", in E. Kreike and W.C. Jordan (eds.), Corrupt Histories (Rochester, NY: University of Rochester Press, 2004).

Ekeh, P., Colonialism and the Two Publics in Africa: A Theoretical Statement, 17 Comparative Studies in Society and History, no. 1 (1975), 91-112.

Finnemore, M. and K. Sikkink, International Norm Dynamics and Political Change, 52 International Organization, no. 4 (1998), 887-917.

Friedman, L., Legal Culture and Social Development, 4 Law and Society Review, no. 29 (1969), 29.

Genaux, M., "Early Modern Corruption in English and French Fields of Vision”, in A.J. Heidenheimer and M. Johnston (eds.), Political Corruption, Concepts and Contexts, 4th ed. (New Brunswick, N): Transaction Publishers, 2002).

Harling, P., The Waning of "Old Corruption": The Politics of Economical Reform in Britain, 1779-1846 (Oxford: Oxford University Press, 1996).

Hill, L., Adam Smith and the Theme of Corruption, 68 The Review of Politics (2006), 638-662. Jensen, M.F., The Question of How Denmark Got to Be Denmark: Establishing Rule of Law and Fighting Corruption in the State of Denmark 1660-1900, QoG Working Paper Series, 18 November 2014. Joseph, R. Democracy and Prebendal Politics in Nigeria: The Rise and Fall of the Second Republic (Cambridge: Cambridge University Press, 1988). 
Kerkoff, T. et al., Corruption and the Rise of Modern Politics in the Eighteenth and Nineteenth Centuries: A Comparison Between France, the Netherlands, Germany and England at https://www.academia.edu/2906809/Corruption_and_the_Rise_of_Modern_Politics_in_ Europe_in_the_Eighteenth_and_Nineteenth_Centuries_A_Comparison_between_France_ the_Netherlands_Germany_and_England

Klaveren, V.J., “Corruption as a Historical Phenomenon”, in Heidenheimer \& Johnston (eds.), Political Corruption: Concepts and Contexts, 4th ed. (New Brunswick, NJ: Transaction Publishers, 2002).

Leith, J.C., Why Botswana Prospered (Montreal \& Kingston: McGill Queens University Press, 2003).

Mamdani, M., Citizen and Subject: Contemporary Africa and the Legacy of Late Colonialism (Princeton: Princeton University Press, 1996).

Mbaku, J.M., Bureaucratic Corruption in Africa: The Futility of Cleanups, 16 The Cato Journal, no. 1 (Spring/Summer, 1996), 99.

Mbaku, J.M., Corruption in Africa: Causes, Consequences, and Cleanups (Lanham: Lexington Books, 2007).

Merry, S.N., Colonizing Hawai'i: The Cultural Power of Law (Princeton: Princeton University Press, 2000).

Mungiu-Pippidi, A., The Quest for Good Governance: How Societies Develop Control of Corruption (Cambridge: Cambridge University Press, 2015).

North, D., Institutions, Institutional Change, and Economic Performance (New York: Cambridge University Press, 1990).

Nwabueze, R.N., The Dynamics and Genius of Nigeria's Indigenous Legal Order, 1 Indigenous L.J. (Spring, 2002), 153-200.

Ostrom, E., Governing the Commons: The Evolution of Institutions for Collective Action (New York: Cambridge University Press, 1990).

Parsons, T., "The Law and Social Control", in W.M. Evan (ed.), Law and Sociology (New York: The Free Press of Glencoe, 1962).

Posner, E., Law and Social Norms (Cambridge, Mass.: Harvard University Press, 2002).

Prest, W., Judicial Corruption in Early Modern England, Past and Present, 133 (Nov., 1991), 67-95.

Proehl, P., Book Review, 42 Indiana L.J. (1967), 277.

Ramseger, F., Historical Perspectives on Corruption in Europe, Utstein Anti-Corruption Centre, 26 February, 2007:<http://www.u4.no/publications/historical-perspectives-on-corrup tion- in-europe/>

Riggs, F.W., "Modernization and Political Problems: Some Developmental Prerequisites", in W.A. Beling and G.O. Totten (eds.), Developing Nations: Quest for a Model (New York: Van Nostrand Reinhold, 1970).

Rubinstein, W., The End of "Old Corruption" in Britain 1780-1860, Past and Present, 101 (1983), 55.

Samatar, A.S., An African Miracle: State and Class Leadership and Colonial Legacy in Botswana Development (Portsmouth, NH: Heinemann, 1999).

Sandbrook, R. et al., Social Democracy in the Global Periphery: Origins, Challenges, Prospects (Cambridge: Cambridge University Press, 2007).

Scott, W.R., Institutions and Organizations: Ideas, Interests and Identities, 4th ed. (Los Angeles: Sage Publications, 2014).

Seidman, R.B., The State, Law and Development (London: Croom Helm, 1978).

Seidman, R.B. and Seidman, State and Law in the Development Process: Problem-Solving and Institutional Change in the Third World (New York: St. Martin's Press, 1994). 
Smith, D.J., A Culture of Corruption: Everyday Deception and Popular Discontent in Nigeria

(Princeton, NJ: Princeton University Press, 2008).

Swart, K., "The Sale of Public Office", in Heidenheimer \& Johnston (eds.), Political Corruption: Concepts and Contexts (New Brunswick, NJ: Transaction Publishers, 2002).

Tafirenyika, M., Information Technology Super-Charging Rwanda's Economy, Africa Renewal (April, 2011): http://www.un.org/africarenewal/

Tamanaha, B.Z., Law as a Means to an End: Threat to the Rule of Law (Cambridge: Cambridge University Press, 2006).

Trubek, D.M., Toward a Social Theory of Law: An Essay on Law and Development, 82 Yale L.J. (1972), 1.

Weingast, B.R., “Constructing Self-Enforcing Democracy in Spain”, in I.L. Morris et al. (eds.), Politics from Anarchy to Democracy (Stanford: Stanford University Press, 2004). 